\title{
LITERASI FINANSIAL PADA TAMAN BACA MASYARAKAT
}

\author{
Hanjar Ikrima Nanda*, Ria Zulkha Ermayda, Fitri Purnamasari, \\ Nabila Dini Syara, Mochammad Galih Satriyo \\ Fakultas Ekonomi, Universitas Negeri Malang \\ email: hanjar.ikrima.fe@um.ac.id
}

\begin{abstract}
Self-management by the owners of the Community Reading Park (TBM), often accompanied by financial problems that threaten its continuity. Lack of knowledge from the management of this nonprofit organization can be minimized by providing workshops related to the financial management of similar organizations. Funds from donations - both cash and non-cash-should be received, recorded, and reported both properly and attractively, thereby increasing donor trust. The purpose of this series of activities is to provide technical skills related to the preparation of TBM financial reports that are easily understood by stakeholders, using excavating problems, providing material and practice as the methods. The first activity carried out was a leadership group discussion whose results helped the next activity to be on target. The next activity is a workshop about recording practices and the making of interesting financial statements that easy to be understand. The community service activity was responded positively by the participants, and they began to commit to an orderly record of cash and non-cash donations at their respective TBMs.
\end{abstract}

Keywords: Financial Reports, Non-Profit Organization

\begin{abstract}
Abstrak
Pengelolaan mandiri oleh pemilik Taman Baca Masyarakat (TBM), seringkali dihampiri oleh masalah keuangan yang cukup mengancam kontinuitasnya. Kurang pengetahuan dari pengurus organisasi nirlaba ini dapat diminimalisir dengan memberikan lokakarya terkait pengelolaan keuangan organisasi sejenis. Dana dari donasi-baik tunai maupun non tunai-seyogyanya diterima, dicatat, serta dilaporkan dengan baik dan menarik, sehingga meningkatkan kepercayaan donatur. Tujuan dari rangkaian kegiatan ini adalah untuk memberikan keterampilan teknis terkait pembuatan laporan keuangan TBM yang mudah dipahami oleh para stakeholder, dengan menggunakan metode berupa penggalian masalah, pemberian materi serta praktik. Kegiatan pertama yang dilakukan adalah leadership group discussion yang hasilnya membantu kegiatan berikutnya agar tepat sasaran. Kegiatan selanjutnya yaitu lokakarya yang diselenggarakan dalam bentuk praktik pencatatan dan juga penyajian laporan keuangan yang menarik serta mudah dipahami. Kegiatan pengabdian ini direspon positif oleh peserta, dan mereka mulai berkomitmen untuk tertib mencatat donasi tunai dan non tunai di TBM masing-masing.
\end{abstract}

Kata kunci: Laporan Keuangan, Organisasi Nirlaba

\section{PENDAHULUAN}

Taman Baca Masyarakat (TBM) dengan berbagai jenis penyebutannya merupakan jenis organisasi nirlaba yang bergerak di bidang pendidikan dan sosial. Kegaitan utamanya biasanya berupa penyediaan buku-buku yang gratis dipinjam oleh masyarakat, dengan berbagai rentang usia. Selayaknya organisasi nirlaba yang lain, TBM juga seringkali mengadakan kegiatan tanpa pungutan biaya seperti meminjam buku gratis, kegiatan belajar bersama, sharing keterampilan, dan lain sebagainya. Organisasi sosial ini 
biasanya dipelopori oleh individu, dan selanjutnya dikelola oleh individu maupun suatu kelompok. Keberadaan perpustakaan dalam komunitas masyarakat sering muncul karena salah satunya adalah adanya keinginan dari suatu organisasi untuk membangun (Sutarno, 2008). Oleh karena itu sesuai dengan bentuknya sebagai organisasi nirlaba, maka TBM rata-rata dikelola secara pribadi maupun oleh sekelompok kecil, dan segala kegiatan di dalamnya diorganisir secara private. Hal ini sesuai dengan karakteristik organisasi nirlaba, yaitu terorganisir, private, mengelola dirinya sendiri, tidak melakukan distribusi pendapatan kepada anggotanya, serta memiliki partisipasi yang bersifat sukarela (Salamon \& Anheier, 1992).

Hasil FGD besama TBM dan juga Komunitas Perpustakaan di Malang, yang diadakan oleh Ruang Belajar Aqil pada Januari 2019, menunjukkan adanya permasalahan di bidang keuangan TBM maupun Komunitas Perpustakaan. Masalah semacam ini juga ditemukan pada organisasi nirlaba umumnya mengalami tiga masalah yaitu (1) sumber dana, (2) sumber daya manusia, dan juga (3) pengelolaan keuangan. TBM yang seringkali dihidupi oleh pendirinya, tanpa bisa mengandalkan donatur, seringkali terhambat perkembangannya karena keterbatasan modal (Allison \& Kaye, 2004).

Sumber daya pengelola TBM terkadang juga kurang memahami masalah pelaporan keuangan dan berimbas pada pembatasan penerimaan donasi tunai, yang akhirnya mengurangi modal organisasi untuk berkembang. Pengelola TBM di Malang sebenarnya ingin melakukan transparansi penggunaan donasi, terutama kepada donatur agar senantiasa dipercaya. Hambatan dari akuntabilitas tersebut adalah kebingungan pengelola TBM tentang teknis pelaporan keuangan. Hal inilah yang melandasi pentingnya kegiatan pengabdian masyarakat ini, yaitu untuk membantu pengelola TBM agar literate terhadap keuangan organisasi, sehingga mampu membuat laporan keuangan yang mudah dipahami berbagai pihak, terutama donatur.

\section{METODE PENGABDIAN}

Pengelola Taman Baca Masyarakat (TBM) maupun Komunitas Perpustakaan yang ada di Malang menjadi sasaran utama kegiatan pengabdian masyarakat saat ini. Sepertiga dari peserta merupakan pengelola yang mengikuti kegiatan Focus Group Discussion (FGD) pada Januari 2019, di mana kegiatan tersebut diselenggarakan oleh mitra yaitu Ruang Belajar Aqil. Pihak akademisi yang sebelumnya telah mengikuti FGD di awal tahun juga diundang untuk memperkuat fenomena yang akan dipecahkan.

Kegiatan pengabdian ini dilakukan dengan dua tahap, yaitu (1) Leadership Group Discussion (LGD), dan (2) Lokakarya Literasi Finansial. Tujuan dari LGD adalah menggali lebih dalam masalah yang telah ditemukan ketika FGD, dan secara bersama-sama merumuskan solusi pemecahannya. LGD ini dirasa perlu, mengingat dalam pendidikan andragogi (orang dewasa), keterlibatan orang dewasa dalam proses belajar jauh lebih besar. Oleh karena itu sejak awal harus diadakan suatu diagnosa kebutuhan, merumuskan tujuan, dan mengevaluasi hasil belajar serta mengimpelmentasikannya secara bersamasama, sehingga materi yang akan disampaikan sesuai dengan kebutuhan hidup perserta (Sunhaji, 2013; Asmin; Tamat, 1985). Hasil FGD akan diimplementasikan dalam bentuk pemberian materi pada saat kegiatan lokakarya.

Kegiatan kedua, yaitu Lokakarya dilaksanakan dengan mengundang seluruh pengelola TBM maupun Komunitas Perpustakaan di Malang yang tergabung dalam Forum Komunikasi Taman Baca Masyarakat (FKTBM). Lokakarya 
diadakan dalam bentuk pemberian materi, tanya-jawab, dan juga praktik simulasi pengelolaan keuangan. Materi diberikan dengan memanfatkan media powerpoint, flip chart, dan form untuk studi kasus. Pemanfaatan media diharapakan dapat membantu peserta didik untuk lebih memahami materi ajar, agar semakin banyak indra yang terlibat dan hasil belajar juga kian bagus (Yusri \& Husaini, 2017).

Metode praktik simulasi dipilih sebagai salah satu metode penyampaian materi, mengingat rata-rata peserta adalah orang dewasa. Pada pendidikan andragogi (orang dewasa), metode latihan simulasi dapat menjadi salah satu pilihan untuk meningkatkan pengalaman peserta didik (Tamat, 1985). Konsep learning by doing juga selaras dengan pendidikan orang dewasa yang dilakukan dalam bentuk praktik pencatatan sesuai dengan kondisi di lapangan, yang melalui empat tahapan yaitu (1) adanya suatu aktivitas (2) adanya proses diskusi, (3) adanya proses perenungan, dan (4) adanya proses rancangan tindak lanjut atau penerapan (Dewi, 2015). Lokakarya ini diadakan pada 24 Agustus 2019 di Universitas Negeri Malang, mulai pukul 08.00 sampai dengan 13.30 WIB.

\section{HASIL DAN PEMBAHASAN}

Literasi finansial menjadi masalah utama yang disasar pada kegiatan pengabdian masyarakat saat ini, mengingat pengaruh literasi keuangan terhadap inklusi dan perilaku keuangan (Yushita, 2017).. Hasil FGD pada bulan Januari (kegiatan sebelumnya) ditindaklanjuti sebagai kegiatan awal dari pengabdian masyarakat saat ini. Berbagai pihak yang sebelumnya mengikuti FGD diundang kembali untuk mengikuti LGD yang diadakan di Ruang Belajar Aqil. Pihak-pihak berasal dari pengelola TBM yang ada di Malang, dan juga beberapa akademisi yang berasal dari lingkungan universitas. LGD bertajuk literasi finansial di perkotaan ini dihadiri oleh 15 orang. Gambar 1 menunjukkan proses LDG yang berlangsung dengan saling tanggap antar peserta yang hadir.

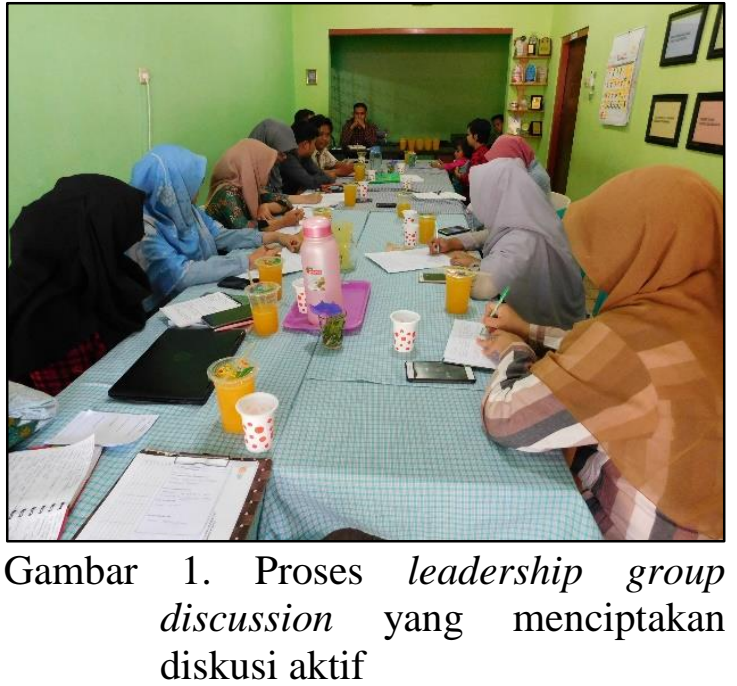

Hasil dari LGD menghasilkan beberapa hal, diantaranya yang akan ditanggapi lebih lanjut untuk membantu memecahkan masalah literasi finansial di TBM, pada kegiatan berikutnya. TBM cenderung lebih suka menerima donasi non tunai daripada tunai, dikarenakan kurang percaya diri dalam melaporakan hasil penggunaan keuangan. Ibu pengurus TBM Teras Literasi (TBM TL) mengatakan jika selama ini lebih suka menerima donasi non tunai, dan jika butuh pendanaan biasanya dari keluarga. Namun beliau mengatakan terdapat masalah dalam memisahkan keuangan organisasi dan keuangan keluarga, sehingga juga membutuhkan solusi terkait hal ini. Pada saat LGD, telah ditemukan usulan terkait teknik pemisahan kekayaan rumah tangga dan organisasi, yaitu menggunakan sistem amplop, sebagaimana yang dilakukan oleh Ibu Rini sebagai perwakilan ibu PKK di daerah perkotaan.

Terkait pelaporan keuangan, selama ini yang dilakukan hanyalah melaporkan secara lisan di forum-forum warga sekitar TBM, sehingga kemungkinan terjadinya disrupsi informasi juga cukup tinggi. Ratarata pemilik juga akan menginformasikan kegiatan yang akan diselenggaran TBM, ketika ada forum pertemuan warga, namun hanya warga yang hadir di dalam forum atau yang bertanya langsung ke pengurus organisasi yang mengetahui laporan yang disampaikan. Bagaimanapun informasi 
tentang kegiatan yang direncakan akan dilaksanakan biasanya tetap tersampaikan, yang ditunjukkan dengan banyaknya warga yang memberikan donasi non tunai. Ibu pengurus TBM TL mengatakan sebagai berikut.

"Biasanya menyampaikan laporan di TL tentang kegiatan yang dilakukan, donasinya apa, disalurkan untuk apa saja, pada kegiatan PKK atau bapak-bapak. Mereka antusias membantu, tiba-tiba di rumah ada cincau ketika akan ada pelatihan membuat es...."

Pada prinsipnya pelaporan keuangan perlu dilakukan untuk meningkatkan kepercayaan bagi stakeholdernya. Sekalipun sederhana, pelaporan keuangan ini harus secara rutin dibuat, dan juga disampaikan ke warga dengan bahasa yang mudah dipahami. Bapak Bari dari perwakilan akademisi mengatakan bahwa tujuan utama pembuatan laporan keuangan adalah agar mudah dipahami oleh para pemangku kepentingannya, sehingga sekalipun hanya berbentuk catatan keluar dan masuknya donasi, maka perlu rutin diadakan dan diharapkan mampu menjaga kepercayaan donatur. Hal ini sesuai dengan apa yang dinyatakan oleh PSAK No. 45, bahwa tujuan utama laporan keuangan organisasi nirlaba adalah untuk menyediakan informasi yang relevan utnuk memenuhi kepentingan pemberi sumber daya yang tidak mengharapkan pembayaran kembali, anggota, kreditur, dan pihak lain yang menyediakan sumber daya bagi entitas nirlaba. Oleh karena itu pembuatan laporan keuangan, sekalipun sederhana, sangat diperlukan oleh TBM untuk dilaporakan ke donatur, pengguna, maupun pihak berkepentingan lain.

Namun fenomena lebih sukanya TBM untuk menerima donasi non tunai, baik berupa makanan, alat tulis, buku, atau yang lainnya, menyebabkan sumber dana pengadaan kegiatan tak berbayar mengandalkan kantong pengelolanya. Hal ini dapat menjadi masalah karena dirasa pendanaan dari katong pengelola tidak dapat selamanya diandalkan untuk organisasi yang kain berkembang. Oleh karena itu materi yang dirasa butuh disampaikan pada kegiatan selanjutnya (lokakarya) yaitu terkait dengan pentingnya pelaporan keuangan dan pelaporan aktivitas organisasi secara tertulis. Peserta juga perlu untuk dilatih terkait dengan teknik pencatatan, pengorganisasian, dan pembuatan laporan keuangan, serta publikasi laporan yang menarik. Perihal terkait cara-cara menggalang dana tanpa mengandalkan donatur juga akan disinggung pada kegiatan lokakarya.

Lokakarya dihadiri oleh 40 peserta yang berasal dari 15 pengelola TBM maupun pengurus organisasi perpustakaan yang ada di Malang dan sekitarnya. Peserta mendapatkan tiga materi, yaitu (1) pentingnya pengelolaan keuangan; (2) bagaimana teknik mengelola keuangannya; dan (3) teknik pembuatan laporan organisasi yang menarik. Materi disampaikan oleh pemateri yang telah memiliki pengalaman terkait pengelolaan keuangan taman baca, yang berasal dari Ruang Belajar Aqil (RBA). Materi pertama yang disampaikan terkait dengan urgensi pengelolaan keuangan, untuk memotivasi peserta dan menarik perhatian peserta di awal sesi(primacy), yang selaras dengan prinsip pengajaran orang dewasa (Sunhaji, 2013).

Materi pengelolaan keuangan dibuka dengan mengenalkan siapa saja sumber daya organisasi, dan bagaimana sifat keuangan. Peserta juga dikenalkan dengan istilah "hulu" dan "hilir" yang sebaiknya seimbang. Hulu terkait dengan pemasukan, penerimaan, dan pendapatan TBM. Hilir terkait dengan pengeluaran, belanja, dan biaya yang dikeluarkan oleh TBM. Materi pertama disampaikan oleh pendiri RBA, yang selama ini berkomitmen untuk melaporkan segala pemasukan dan pengeluaran organisasi, sekalipun tidak material, dan juga melaporkan aktivitas sekecil apapun. Hal tersebut menjadi sentilan khusus bagi para peserta, karena ternyata ketekunan untuk menulis hal sekecil apapun terkait organisasi, baik 
keuangan maupun non keuangan, akan berdampak besar terhadap organisasi. Hal ini dapat meningkatkan kepercayaan donatur, yang diharapkan senantiasa mendukung perkembangan organisasi.

Materi kedua terkait dengan strategi, teknik dan instrumen dalam mengelola keuangan. Materi ini disampaikan oleh dua orang pengurus di RBA. Peserta dikenalkan dengan beberapa formulir yang digunakan oleh RBA untuk mengelola keuangannya, mulai dari pemasukan, alokasi, dan juga pencatatan pengeluarannya. Sama halnya dengan apa yang dilakukan di masa Umar bin Abdul Aziz, di mana keuangan publik terkait dengan dua hal, yaitu pengelolaan penerimaan negara, dan pengelolaan pengeluaran atau alokasi (Kuliman, 2016). Hal tersebut sebaiknya dilakukan untuk menciptakan kesejahteraan rakyat, yang jika ditarik ke TBM berarti mensejahterakan para penggunanya.

Terkait dengan pengelolaan pengeluaran TBM, pemateri memberikan contoh pembagian pengeluaran ke dalam dua jenis, yaitu pengeluaran operasional dan pengeluaran rumah tangga. Pengeluaran operasional terkait dengan pengadaan kegiatan bagi kesejahteraan pengguna organisasi, sedangkan pengeluaran rumah tangga terkait dengan pengeluaran rutin organisasi seperti sewa tempat untuk aktivitas organsiasi. Hal ini juga mirip dengan apa yang dilakukan oleh Umar bin Abdul Aziz, yang membagi pengeluaran Baitul Mal ke dalam dua hal, untuk kepentingan masyarakat umum, dan untuk pentingan negara (Kuliman, 2016).

Semua bentuk pemasukan dan pengeluaran ini diharapkan akan seimbang di akhir tahun, di mana sisa saldo adalah nol (0). Pemateri medorong peserta untuk mengelola keuangan secara transparan, akuntabel, profesional, dan amanah. Peserta juga dimotivasi untuk tidak perlu ragu menerima donasi berbentuk kas, dan berkomitmen menghabiskan seluruh dana yang tersedia pada setiap tahunnya untuk memberikan manfaat bagi pengguna TBM, misalnya mengadakan lokakarya gratis bagi guru TK, perpustakaan keliling di beberapa sekolah, dan lain sebagainya.

Materi ketiga terkait dengan teknik penyajian laporan organisasi yang menarik, baik laporan keuangan maupun laporan kegiatan. Desain infografis dipraktikkan secara manual oleh peserta, berdasarkan studi kasus dari data sebelumnya. Prinsip yang digunakan adalah informatif dan artistik. Antusiasme peserta dapat dilihat dari goresan crayon dan berbagai bentuk grafis dasar yang telah mereka kembangkan berdasarkan kreatifitas masing-masing. Gambar 2 menunjukkan proses penyampaian materi oleh pemateri, yang disimak oleh peserta dengan sungguhsungguh.

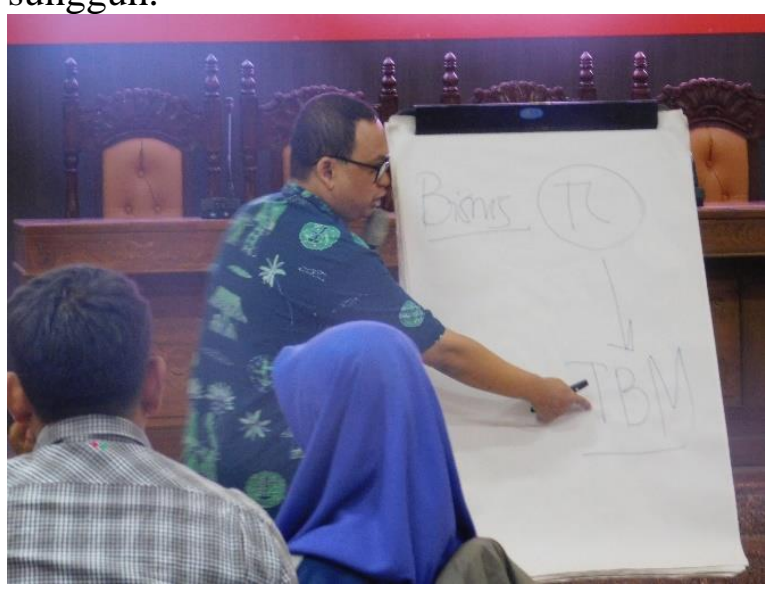

Gambar 2. Salah satu pemateri lokakarya sedang menyampaikan materi

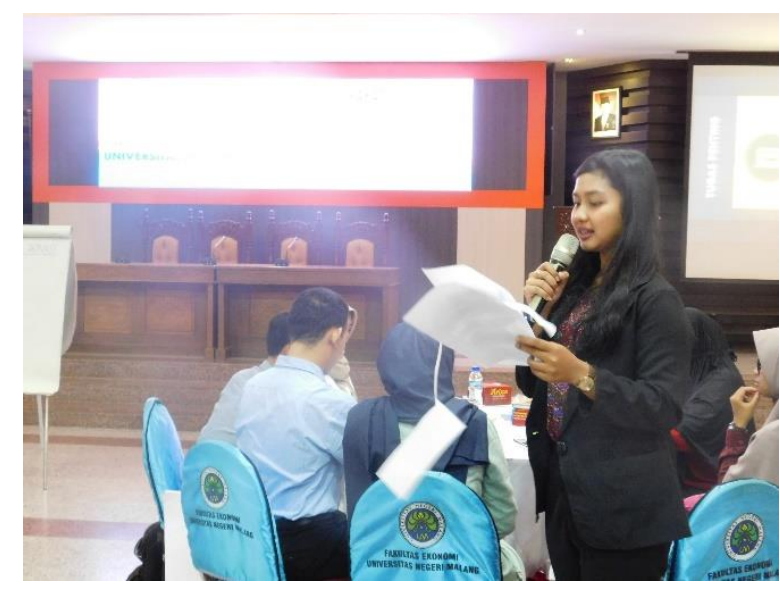

Gambar 3. Proses tanya-jawab antara peserta dengan pemateri

Secara keseluruhan teknis ketiga materi ini berbentuk ceramah, tanya jawab, dan disertai praktik. Salah satu bentuk proses 
tanya jawab, dapat dilihat pada gambar 3. Praktik diadakan setelah materi disampaikan, sebelum lanjut ke materi berikutnya. Praktik dirasa menjadi salah satu alternatif yang mampu menggiring peserta yang berusia dewasa untuk memahami inti dari materi yang disampaikan. Keunikan dari tiam TBM tidak akan lepas, sekalipun praktik terbimbing diadakan. Praktik yang disertai dnegan pemecahan masalah, latihan, dan simulasi memang menjadi salah satu metode andalan di pendidikan orang dewasa sebagaimana yang disampaikan oleh (Sunhaji, 2013).

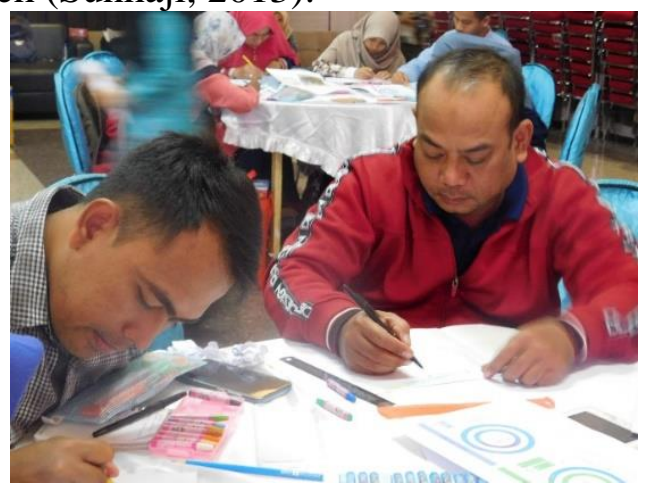

Gambar 4. Peserta sedang praktik membuat laporan berbentuk desain grafik menggunakan media crayon

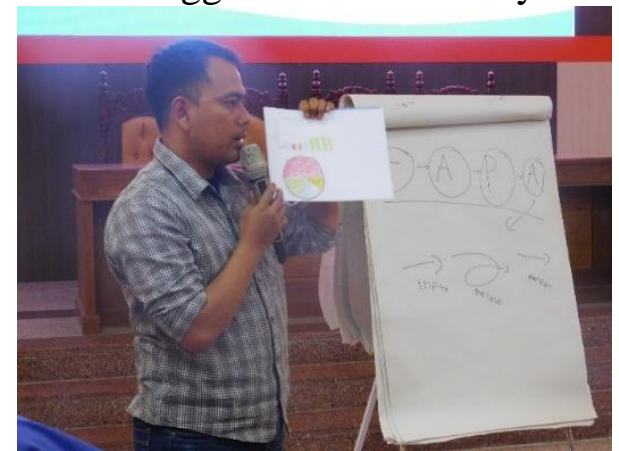

Gambar 5. Perwakilan peserta sedang menunjukkan hasil praktik pembuatan laporan berbentuk desain grafis

Peserta antusias mengikuti setiap rangkaian kegiatan, yang tampak dari keaktifan mereka untuk bertanya lebih lanjut dan juga dari hasil penyamapaian kesan dan pesan, baik lisan maupun tertulis. Pak Budi dari TBM Enggal Permata (TBM EP) menyatakan bahwa materi yang disampaikan bisa dipraktikkan di anggaran rumah tangga di TBM EP, di mana selama ini sangat susah untuk menertibkan pencatatan keuangan organisasi. Lebih lanjut beliau menyampaikan jika praktik yang diberikan pada lokakarya saat ini telah banyak output yang bermanfaat, dan diharapkan segera dapat dipraktikkan di TBMnya. Secara tertulis sebagian peserta juga mengungkapkan jika akan segera menerapkan hasil lokakarya ini di TBM masing-masing, dan juga menularkan ilmunya kepada para rekannya di TBM. Mereka berharap kegiatan semacam ini dapat terus dilaksanakan untuk mendukung kemajuan dan kontinuitas TBM yang mereka kelola.

\section{SIMPULAN}

Rangkaian kegiatan untuk membantu pengurus TBM literate terhadap pengelolaan keuangan organisasi nirlaba memberikan hasil yang positif. Kegiatan FGD yang sebelumnya dilakukan, telah ditindaklanjuti dengan LGD yang kian mengerucutkan masalah keuangan yang dihadapi TBM. LGD juga telah membantu merumuskan materi yang sesuai untuk disampaikan dan bagaimana teknis penyampaian materi yang sebaiknya diterapkan. Selanjutnya kegiatan lokakarya menjadi lebih efektif berjalan sesuai dengan harapan, karena adanya persiapan matang teknis penyampaian materi untuk orang dewasa. Pada akhirnya kegiatan pengabdian masyarakat ini direspon positif dan mampu memotivasi peserta untuk mulai menerapkan di TBM masing-masing, yaitu tertib mencatat keuangan, mengelola, dan juga melaporan ke para pemangku kepentingan dengan semenarik mungkin. Mereka juga antusias jika kegiatan semacam ini ditindaklanjuti ke depannya, misalnya dengan praktik penyelesaian masalah bisa lebih sesuai dengan kondisi organisasi yang unik. Ke depan, sebaiknya kegiatan dilanjutkan dengan pendampingan sehingga dapat dipecahkan bersama terkait permasalahan selama praktik pengelolaan keuangan lebih terkontrol dan lebih maksimal di TBM masing-masing. 


\section{UCAPAN TERIMA KASIH}

Ucapan terimakasih penulis sampaikan kepada Lembaga Penelitian dan Penabdian Masyarakat (LP2M) Universitas Negeri Malang yang telah memberikan dukungan pendanaan dan moral, sehingga kegiatan ini dapat terlaksana dengan baik. Terimakasih juga penulis sampaikan kepada mitra kegiatan yang berperan aktif membantu suksesnya pelaksanaan kegiatan ini, yaitu Ruang Belajar Aqil. Namun secara umum kegiatan ini tidak akan terlaksana tanpa partisipasi peserta, yang berasal dari TBM di Malang. Oleh karena itu penulis sampaikan terimakasih sebesar-besarnya kepada para peserta yang telah antusias dan berkomitmen mengikuti rangkaian kegiatan ini dari awal hingga akhir.

\section{DAFTAR PUSTAKA}

[1] Allison, M., \& Kaye, J. (2004). Perencanaan Strategi. Jakarta: Yayasan Obor Indonesia.

[2] Asmin. (n.d.). Konsep dan Metode Pembelajaran untuk Orang Dewasa (Androgogi). Retrieved from Fakultas Ilmu Pendidikan Universitas Pendidikan Indonesia: http://file.upi.edu/Direktori/FIP/JUR. _PEND._LUAR_SEKOLAH/19510 9141975011-

AYI_OLIM/andragogi_PDF2.pdf

[3] Dewi, R. R. (2015, April 6). Model Proses Androgogi untuk Pembelajaran. Retrieved from Berbagi Pengetahuan: http://rinitarosalinda.blogspot.com/2 015/04/model-proses-andragogiuntuk.html

[4] Ikatan Akuntan Indonesia (IAI). (2011). Pernyataan Standar Akuntansi Indonesia (PSAK) No. 45 tentang Pelaporan Keuangan Organisasi Nirlaba. Jakarta: Ikatan Akuntan Indonesia.

[5] Kuliman. (2016). Kebijakan Pengelolaan Keuangan Publik pada Masa Kekhalifahan Umar bin Abdul Azis. Jurnal Ipteks Terapan, 59-66.
[6] Salamon, L. M., \& Anheier, H. K. (1992). In Search of The Nonprofit Sector: The Question of Definition. Journal of Voluntary and Nonprofit Organization, 125-151.

[7] Sunhaji. (2013). 2013. Jurnal Kependidikan, 1.

[8] Sutarno, N. S. (2008). Perpustakaan dan Masyarakat. Jakarta: Sagung Seto.

[9] Tamat, T. (1985). Dari Pedagogik ke Androgogik. Jakarta: Pustaka Dian

[10] Yushita, A. N. (2017). Pentingnya Literasi Keuangan Bagi Pengelolaan Keuangan Probadi. Jurnal Nominal, 11-26.

[11] Yusri, R., \& Husaini, A. (2017). Pengembangan Multimedia Interaktif Menggunakan Microsoft Power Point dalam Pembelajaran Matematika Kelas X. Jurnal Ipteks Terapan, 1-8. 